\title{
Phytochemistry, Antioxidant Activity, Antiproliferative Effect, and Acute Toxicity Testing of Two Moroccan Aristolochia Species
}

\author{
Mohammed Bourhia $\left(\mathbb{D},{ }^{1}\right.$ Fatima Ezzahra Laasri $\left(\mathbb{D},{ }^{2,3}\right.$ Samir Iben Moussa, ${ }^{1}$ Riaz Ullah $\left(\mathbb{D},{ }^{4}\right.$ \\ Ahmed Bari, ${ }^{5}$ Syed Saeed Ali, ${ }^{5}$ Aghmih Kaoutar, ${ }^{6,7}$ Amal Ait Haj Said, \\ Mohammed El Mzibri $\mathbb{D},{ }^{2}$ Gmouh Said, ${ }^{9}$ Naima Khlil, ${ }^{1}$ and Laila Benbacer $\mathbb{D}^{2}$ \\ ${ }^{1}$ Laboratory of Chemistry, Biochemistry, Nutrition, and Environment, Faculty of Medicine and Pharmacy, \\ University Hassan II, Casablanca, Morocco \\ ${ }^{2}$ Research Unit and Medical Biology, National Center for Nuclear Energy, Science and Technology (CNESTEN), \\ Rabat 10001, Morocco \\ ${ }^{3}$ Laboratory of Nutrition, Health and Environment, Faculty of Sciences, Ibn Tofail University, Kenitra, Morocco \\ ${ }^{4}$ Medicinal Aromatic and Poisonous Plants Research Center, College of Pharmacy, King Saud University, P. O. Box 2457, \\ Riyadh 11451, Saudi Arabia \\ ${ }^{5}$ Central Laboratory, College of Phamacy, King Saud University, P. O. Box 2457, Riyadh 11451, Saudi Arabia \\ ${ }^{6}$ Laboratory REMTEX, Higher School of Textile and Clothing Industries, Casablanca, Morocco \\ ${ }^{7}$ Laboratory GeMEV, Faculty of Sciences Aïn Chock, Hassan II University, Casablanca, Morocco \\ ${ }^{8}$ Laboratory of Pharmacognosy, Faculty of Medicine and Pharmacy of Casablanca, Hassan II University, Casablanca, Morocco \\ ${ }^{9}$ Laboratory of Engineering and Materials LIMAT, Faculty of Sciences Ben M'Sik, University Hassan II, \\ Casablanca, B. P. 7955, Morocco
}

Correspondence should be addressed to Mohammed Bourhia; bourhiamohammed@gmail.com and Riaz Ullah; rullah@ksu.edu.sa

Received 11 June 2019; Revised 17 September 2019; Accepted 14 October 2019; Published 3 December 2019

Guest Editor: Samuel Martins Silvestre

Copyright (C) 2019 Mohammed Bourhia et al. This is an open access article distributed under the Creative Commons Attribution License, which permits unrestricted use, distribution, and reproduction in any medium, provided the original work is properly cited.

Ethnopharmacological Relevance. Aristolochia baetica (A. baetica) and Aristolochia paucinervis (A. paucinervis) have been largely used in Moroccan folk medicine. The objective of the study was to investigate the phytochemical composition, the antioxidant activity, the antiproliferative effect, and the acute toxicity of the methanolic extract of A. baetica and A. paucinervis roots. Materials and Methods. Phytochemical composition of the methanolic extract of A. baetica and A. paucinervis roots were studied using qualitative and quantitative methods, the antioxidant activity was evaluated using DPPH assay, the antiproliferative effects against human cancer cell lines (T-24, HT-29, and Hep G-2) was assessed using WST1 assay, and the acute toxicity was carried out orally by gavage of single dose $2000 \mathrm{mg} / \mathrm{kg}$ to mice for 14 days. Results. The two studied plants have different classes of secondary metabolites. The concentrations of the total polyphenolic content of A. baetica and A. paucinervis root extracts were estimated at $360 \pm 20 \mathrm{mg} \mathrm{GAE} / \mathrm{g}$ and $280 \pm 27 \mathrm{mg} \mathrm{GAE} / \mathrm{g}$, respectively. The total flavonoids content of A. baetica and A. paucinervis extracts were estimated at $35 \pm 8 \mathrm{mg}$ QE/g and $235 \pm 7 \mathrm{mg} \mathrm{QE} / \mathrm{g}$, respectively. A. baetica and A. paucinervis extracts exhibited promising DPPH activity with $\mathrm{IC}_{50}$ values of $150 \pm 8 \mu \mathrm{g} / \mathrm{ml}$ and $160 \pm 10 \mu \mathrm{g} / \mathrm{ml}$, respectively. The extracts exerted also antiproliferative effects on all tested cancer cell lines (T-24, HT-29, and Hep G-2) with $\mathrm{IC}_{50}$ values ranging from $6 \pm 1 \mu \mathrm{g} / \mathrm{ml}$ to $380 \pm 7 \mu \mathrm{g} / \mathrm{ml}$. Regarding the results of acute toxicity study, no signs of toxicities nor mortalities were observed on the oral treated mice with $2000 \mathrm{mg} / \mathrm{kg}$ of the two investigated exacts. Conclusion. The methanolic extracts of A. baetica and A. paucinervis possess several phytochemicals that exhibited promising free radical scavenging activity and antiproliferative effects.

\section{Introduction}

Sine antiquities, plants have played an important role in our daily lives as they have been a source of food, fiber, and other necessary needs. Among these resources, medicinal plants have been widely used to protect humans against serious diseases $[1,2]$. They are considered as a natural reservoir of biologically active substances with different biological 
properties. These bioactive natural remedies are increasingly used to treat a wide variety of clinical diseases because of its lower side effects [3].

Currently, therapeutic chemistry has great interests in health care, with almost $80 \%$ of the population throughout the world using medicinal plants [4]. As a result, several research studies have paid more attention to medicinal plants as an important source of chemical compounds and bioactive substances with antibacterial, anti-inflammatory, antioxidant, and anticancer activity [5]. Some of the natural substances have been recognized as key players in pharmacology for the development of new drugs used in the treatment of cancer [6]. Scientific research on plants used in traditional medicine is widely required to ensure safety control and to avoid potential risks related to the ingestion of toxic herbs. Data collected from in vitro and in vivo toxicological studies of herbs are needed to consolidate the scientific validity of herbs [7].

Aristolochia species have been widely used in Moroccan traditional medicine to treat various diseases for many years ago [7]. Nowadays, some of these plants are used to treat cancer [8], digestive diseases [9], rheumatic, abortifacient, and cutaneous neoplasm. They are also used as a stimulant of blood circulatory as anti-inflammatory and antiseptic [10].

The present work was conducted to determine the scientific basis of traditional uses of A. baetica and A. paucinervis. It aims at the investigation of the phytochemical composition, the antioxidant activity, the antiproliferative effect, and the acute toxicity of the methanolic extract of the two reported plants.

\section{Materials and Methods}

2.1. Plant Material. A. baetica was collected in January 2016 from the surrounding region of Chefchaouen (Moroccan city). A. paucinervis was harvested in December 2016 at $30 \mathrm{~km}$ East of Khouribga (Moroccan city). The collected plants were identified by Dr. Mohammed Fanane (Department of Botany, Scientific Institute of Rabat, Morocco). A voucher specimen has been deposited in the herbarium under 1045 and 1046, respectively. The roots of both, A. baetica and A. paucinervis were initially cleaned, washed with water, dried in the shade, and chopped into small pieces using an electric mixer.

2.2. Preparation of Plant Extract. $25 \mathrm{~g}$ of dried powder of $A$. baetica and $A$. paucinervis roots was extracted using Soxhlet at $40^{\circ} \mathrm{C}$ for $2 \mathrm{~h}$ using methanol as an extraction solvent. The obtained extract was centrifuged, filtered, and evaporated at low pressure $\left(40^{\circ} \mathrm{C}\right)$ to remove the excess solvent in order to obtain $3 \mathrm{~g}$ of crude extract.

2.3. Phytochemical Screening. The plant materials were subjected to qualitative phytochemical careening in order to qualitatively determine some type of interesting constituents that could be responsible for biological activities. Alkaloids, flavonoids, polyphenols, anthraquinones, saponins, tannins, sterols, and terpenes were the major checked groups using standard methods as reported in earlier literature with slight modifications [11].

2.4. Identification of Bioactive Constituents by GC-MS. GC-MS analysis of the methanolic extracts of the studied plants were performed using a Claus 580 Gas Chromatography according to the following acquisition parameters: oven: initial temp $50^{\circ} \mathrm{C}$ for $2 \mathrm{~min}$, ramp $11^{\circ} \mathrm{C} / \mathrm{min}$ to $200^{\circ} \mathrm{C}$, hold $0 \mathrm{~min}$, ramp $6^{\circ} \mathrm{C} / \mathrm{min}$ to $240^{\circ} \mathrm{C}$, hold $1 \mathrm{~min}$, split $=10: 1$, carrier gas $=\mathrm{He}$, solvent delay $=4.00 \mathrm{~min}$, transfer temp $=280^{\circ} \mathrm{C}$, source temp $=250^{\circ} \mathrm{C}$, scan: 40 to $450 \mathrm{Da}$, and column $30.0 \mathrm{~m} \times 250 \mu \mathrm{m}$.

2.5. Total Polyphenolic Content. The total phenolic content of A. baetica and A. paucinervis extracts was determined using the Folin-Ciocalteu method and gallic acid as standard. Aliquots of test samples $(250 \mu \mathrm{L})$ of a diluted solution of extracts were mixed with $1.5 \mathrm{~mL}$ of sodium carbonate solution (7.5\%). After $5 \mathrm{~min}, 1.25 \mathrm{~mL}$ of Folin-Ciocalteu reagent, reveal the composition of this reagent $(0.2 \mathrm{~N})$, was added to the mixture, allowed to stand at room temperature for $30 \mathrm{~min}$ in darkness. The reading was carried out versus a blank at $765 \mathrm{~nm}$. The calibration curve was plotted using gallic acid as a positive control. The results were expressed as gallic acid equivalent per gram of dry extract (mg GA E/g) [12].

2.6. Total Flavonoid Content. The total flavonoid content of A. baetica and A. paucinervis extracts was identified using the aluminum chloride assay (colorimetry). Each diluted sample was mixed with $1.5 \mathrm{~mL}$ of $\mathrm{AlCl}_{3}(2 \%)$ and incubated for $60 \mathrm{~min}$ at room temperature. The absorbance was read spectrophotometrically against a blank at $415 \mathrm{~nm}$. Quercetin was used as a reference standard compound. The calibration curve was plotted using quercetin as a standard compound. The results were expressed as quercetin equivalent per gram of dry extract (mg QE/g) [13].

2.7. Antioxidant Activity. The antioxidant activity of A. baetica and A. paucinervis extracts was evaluated in vitro using DPPH (2,2-diphenyl-1-picrylhydrazyl) assay according to the method described in previous literature [14]. About $1 \mathrm{ml}$ of methanolic extract at different concentrations ranging from $100 \mu \mathrm{g} / \mathrm{ml}$ to $900 \mu \mathrm{g} / \mathrm{ml}$ was mixed with $500 \mu \mathrm{l}$ of methanolic solution of DPPH $(0.005 \%)$. After $30 \mathrm{~min}$ of incubation in darkness at room temperature, the absorbance (A) of the control and samples was read spectrophotometrically at $517 \mathrm{~nm}$. Ascorbic acid was used as a positive control. The free radical scavenging activity was calculated in percentage as follows:

Free radical scavenging activity $(\%)=\frac{(A) \text { control }-(A) \text { sample }}{(A) \text { control }} * 100$.

$\mathrm{IC}_{50}$ was determined graphically from the graph plotting inhibition percentage against extract [15]. 


\subsection{In Vitro Cytotoxicity Assay}

2.8.1. Cell Culture and Treatment. Three Cancerous cell lines were selected to be tested including human bladder cancer cell lines (T-24). The latter were cultured in McCoys5a; in parallel, the liver cancer cell lines (Hep G-2) and human colon cancer cell lines (HT-29) were cultured in DMEM media added with $10 \%$ heat-inactivated fetal calf serum, antibiotics (1\%), and glutamine (1\%). The cancerous cells were grown at $37^{\circ} \mathrm{C}$ in a humidified incubator set at $5 \% \mathrm{CO}_{2}$. The cultures were left until they formed a monolayer on the flask. The cells were washed with PBS and trypsinized in order to be detached and then adding a complete medium to inhibit the reaction.

Antiproliferative activity of the methanolic extract of $A$. baetica and $A$. paucinervis against T-24, Hep G-2, and HT29 cell lines was assessed on the basis of mitochondrial metabolic activity using WST1 (disodium mono\{4-[3-(4-iodophenyl)-2-(4-nitrophenyl)-2H-tetrazol]-3-ium-5-yl]benzene-1, 3 disulfonate\}). During the exponential growth of the tested cells in 96-well microplates at a density of 8000 cells per well, the seeding medium was removed and replaced by extracts prepared in medium to concentration up ( 0 to $400 \mu \mathrm{g} / \mathrm{mL}$ ). WST1 assay was performed in triplicate, and the mitomycin was used parallelly as positive control. After $72 \mathrm{~h}$ of incubation, briefly $100 \mu \mathrm{l}$ of the medium was removed from each well and $10 \mu \mathrm{l}$ of WST1 solution was added to cultured cells. The plate was incubated again for $4 \mathrm{~h}$ at $37^{\circ} \mathrm{C}$ in a dark wet atmosphere. The absorbance was read at $590 \mathrm{~nm}$ using a Wallac Victor X3 multiwell spectrophotometer.

The percentage of cytotoxicity was defined according to the following formula:

$$
\text { cell death }(\%)=\frac{\text { control OD }- \text { sample OD }}{\text { control OD }} * 100 \text {. }
$$

The percentage of viability was calculated according to the following equation:

$$
\text { cell viability }(\%)=100-(\% \text { cell death }) \text {. }
$$

$\mathrm{IC}_{50}$ value (the inhibition concentration required to reduce $50 \%$ of cell proliferation) was determined graphically on the basis of regression analysis performed on WST1 assay viability [16].

2.9. Animal Material. Adult Swiss albino mice weighing approximately $25 \mathrm{~g}$ were used for acute toxicity. The mice were purchased from the animal colony of Pasteur Institute (Casablanca, Morocco). All animals were kept in polypropylene cages. The animals were acclimatized for one week under laboratory conditions of regular light/dark cycles (12/ $12 \mathrm{~h})$ and temperature $\left(24 \pm 2^{\circ} \mathrm{C}\right)$. The animals had free access to tap water and a normal pellet diet [17].

2.10. Study of Acute Toxicity. Nine male adult mice were randomly divided into three experimental groups of three mice each. The animals were grouped in polypropylene cages and fasted for $12 \mathrm{~h}$. The organic extract of the studied plants was administered to each treatment group once as follows:
Control group - treated with vehicle (distilled water) Group A-A. baetica extract (2000 mg/kg) Group B-A. paucinervis extract $(2000 \mathrm{mg} / \mathrm{kg})$

Animals were observed for signs of toxicity, mortalities, changes in general behavior, and physical appearance. This study was conducted according to the Organization for Economic Cooperation and Development (OECD) Guidelines No. 425 [18].

2.11. Statistical Analysis. Data for each test are the average of triplicate experiments \pm standard deviation (SD), and statistical analysis of difference was performed using ANOVA. The means were compared using the Holm-Sidak Test. Statistically $p$ value less than 0.05 was considered to indicate significance.

\section{Results}

3.1. Phytochemical Screening. The phytochemical screening of $A$. baetica and $A$. paucinervis roots revealed the presence of flavonoids, polyphenols, alkaloids, tannins, saponins, and the absence of anthraquinone, sterols, and terpenes (Table 1).

3.2. GC-MS Analysis. The GC-MS analysis of A. baetica methanolic extract revealed ten compounds: pseudocumene, tetracyclo [3.3.1.0.1(3,9)] decan-10-one, $p$-vinylguaiacol, 2epi-trans- $\beta$-caryophyllene, guaia-6,9-diene, pacifigorgiol, maaliol, methylglucose, isoaromadendrene epoxide, and trans-sinapyl alcohol (Figure 1; Table 2).

Regarding A. paucinervis methanolic extract, the GC-MS identified seven compounds: dihydro-4,4,5,5-tetramethyl 2(3H)-furanone, mesitylene, dodecane, maaliol, 2-palmitoylglycerol, dioctyl terephthalate, phthalic acid, and $\operatorname{di}(2$ propylpentyl) ester (Figure 2; Table 3).

3.3. Total Polyphenolic and Flavonoid Contents. Calculations of total polyphenolic content in the organic extract of the studied plants were based on the equation obtained from the standard gallic acid graph. Total polyphenolic contents of $360 \pm 20 \mathrm{mg} \mathrm{GAE} / \mathrm{g}$ and $280 \pm 27 \mathrm{mg} \mathrm{GAE} / \mathrm{g}$ were found in $A$. baetica and $A$. paucinervis methanolic extracts, respectively. Regarding the total flavonoid content calculation, the formula obtained from the standard quercetin graph was applied. Total flavonoid content of $35 \pm 8 \mathrm{mg} \mathrm{QE} / \mathrm{g}$ was obtained with $A$. baetica extract and $235 \pm 7 \mathrm{mg} \mathrm{QE} / \mathrm{g}$ with $A$. paucinervis extract.

3.4. Antioxidant Activity. The antioxidant activity of $A$. baetica and $A$. paucinervis methanolic extracts was evaluated by the DPPH free radical scavenging test. As shown in Figure 3, both extracts exhibit promising antioxidant activity in a concentration-dependent manner.

The $\mathrm{IC}_{50}$ value (the inhibitory concentration of extract required to inhibit $50 \%$ of the initial $\mathrm{DPPH}$ free radical) of the plant extracts and ascorbic acid as a positive control was 
TABLE 1: Qualitative phytochemical screening of A. baetica and A. paucinervis roots.

\begin{tabular}{lcc}
\hline Phytoconstituents & A. baetica roots & A. paucinervis roots \\
\hline Polyphenols & ++ & +++ \\
Alkaloids & +++ & ++ \\
Flavonoids & +++ & ++ \\
Anthraquinone & - & - \\
Sterols and terpenes & - & - \\
Saponins & + & + \\
Tannins & +++ & ++ \\
\hline
\end{tabular}

+++: strong positive test; ++: positive test; +: low positive test; -: negative test.

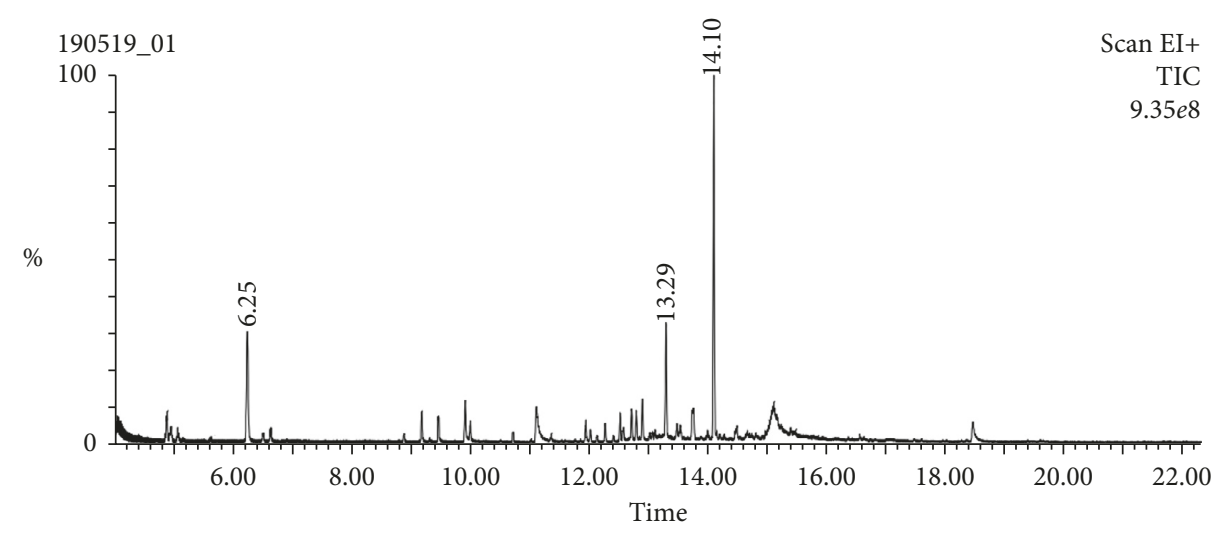

Figure 1: GC-MS spectral chromatogram of A. baetica methanolic extract.

TABle 2: Phytocomponents identified from methanolic extract of A. baetica roots using GC-MS.

\begin{tabular}{lccc}
\hline S. No & Retention time $(\mathrm{min})$ & Compound name & Molecular formula \\
\hline 1 & 6,249 & Pseudocumene & $\mathrm{C}_{9} \mathrm{H}_{12}$ \\
2 & 9,917 & Tetracyclo $[3.3 .1 .0 .1(3,9)]$ decan-10-one & $\mathrm{C}_{10} \mathrm{H}_{12} \mathrm{O}$ \\
3 & 11,118 & -Vinylguaiacol & $\mathrm{C}_{9} \mathrm{H}_{10} \mathrm{O}_{2}$ \\
4 & 12,902 & 2-epi-trans- $\beta$-Caryophyllene & $\mathrm{C}_{15} \mathrm{H}_{24}$ \\
5 & 13,294 & Guaia-6,9-diene & $\mathrm{C}_{15} \mathrm{H}_{24}$ \\
6 & 13,76 & Pacifigorgiol & $\mathrm{C}_{15} \mathrm{H}_{26} \mathrm{O}$ \\
7 & 14,103 & Maaliol & $\mathrm{C}_{15} \mathrm{H}_{26} \mathrm{O}$ \\
8 & 15,11 & Methylglucose & $\mathrm{C}_{7} \mathrm{H}_{14} \mathrm{O}_{6}$ \\
9 & 15,163 & Isoaromadendrene epoxide & $\mathrm{C}_{15} \mathrm{H}_{24} \mathrm{O}$ \\
10 & 18,466 & trans-Sinapyl alcohol & $\mathrm{C}_{1} 7 \mathrm{H}_{24} \mathrm{O}_{9}$ \\
\hline
\end{tabular}

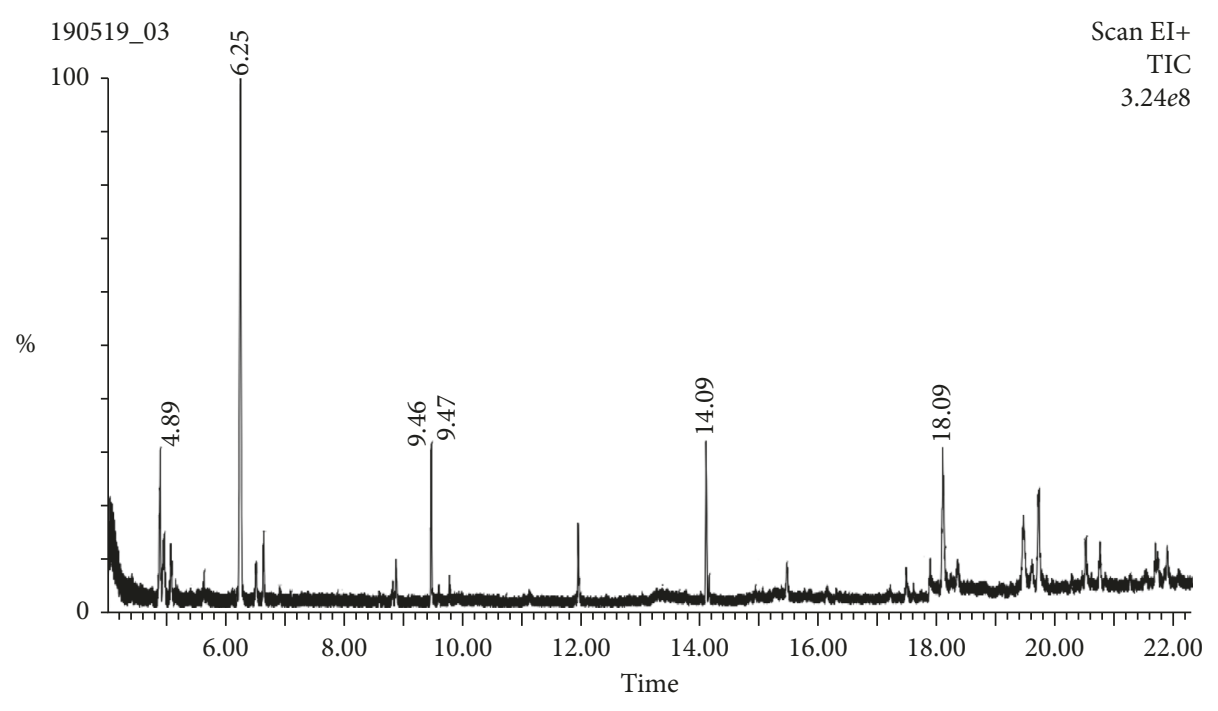

FIGURE 2: GC-MS spectral chromatogram of A. paucinervis methanolic extract. 
TABLe 3: Phytocomponents identified from methanolic extract of A. paucinervis roots using GC-MS.

\begin{tabular}{lccc}
\hline S. No & Retention time $(\mathrm{min})$ & Compound name & Molecular formula \\
\hline 10 & 4,893 & Dihydro-4,4,5,5-tetramethyl 2(3H) furanone & $\mathrm{C}_{11} \mathrm{H}_{16} \mathrm{O}_{4}$ \\
17 & 6,246 & Mesitylene & $\mathrm{C}_{9} \mathrm{H}_{12}$ \\
22 & 9,467 & Dodecane & $\mathrm{C}_{12} \mathrm{H}_{26}$ \\
26 & 14,095 & Maaliol & $\mathrm{C}_{15} \mathrm{H}_{26} \mathrm{O}$ \\
35 & 18,087 & $2-\mathrm{Palmitoylglycerol}$ & $\mathrm{C}_{19} \mathrm{H}_{38} \mathrm{O}_{4}$ \\
39 & 19,447 & Dioctyl terephthalate & $\mathrm{C}_{24} \mathrm{H}_{38} \mathrm{O}_{4}$ \\
41 & 19,712 & Phthalic acid, di $(2$ propylpentyl) ester & $\mathrm{C}_{24} \mathrm{H}_{38} \mathrm{O}_{4}$ \\
\hline
\end{tabular}

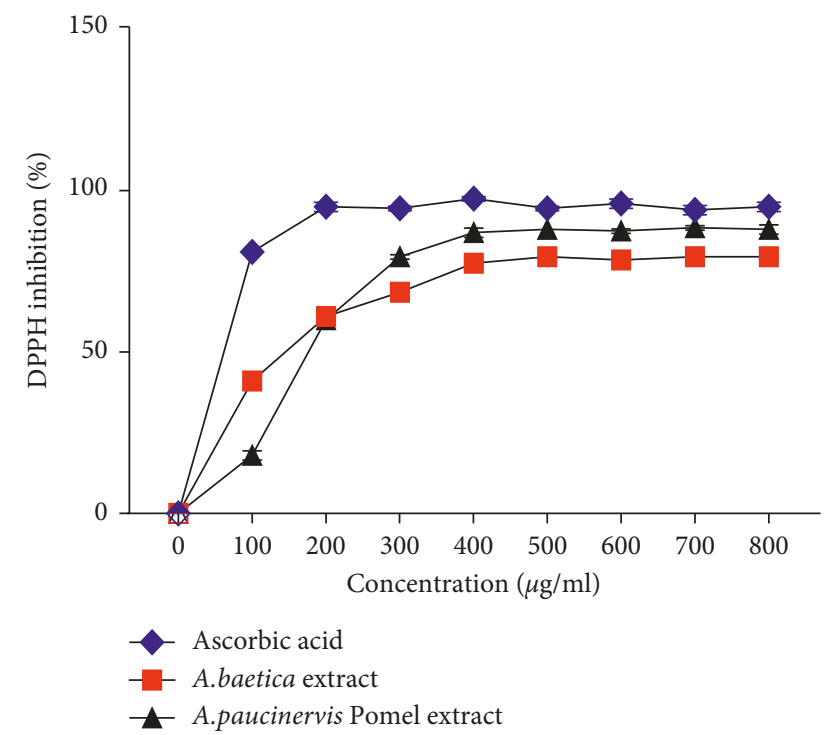

FIGURE 3: DPPH radical scavenging activity of methanolic extract of $A$. baetica and A. paucinervis.

determined graphically from the graph of DPPH inhibition percentage. The results of $\mathrm{IC}_{50}$ values of methanolic extract of A. baetica, A. paucinervis, and ascorbic acid were determined approximately at $150 \pm 8 \mu \mathrm{g} / \mathrm{ml}, 160 \pm 10 \mu \mathrm{g} / \mathrm{ml}$, and $25 \pm 3 \mu \mathrm{g} / \mathrm{ml}$, respectively. In order to perform the comparison, the $\mathrm{IC}_{50}$ values of $\mathrm{DPPH}$ radical scavenging activity of methanolic extract of A. baetica and A. paucinervis showed a significant difference compared to DPPH $\mathrm{IC}_{50}$ value of ascorbic acid as a standard $\left(p^{* * *}<0.05\right)$.

3.5. In Vitro Cytotoxicity Assay. The methanolic extract of $A$. baetica and A. paucinervis was investigated for potential antiproliferative effects on T-24, Hep G-2 and HT29 human cancerous cell lines using WST1 assay. Figures 4 and 5 show important antiproliferative effects induced by the investigated extracts on the treated cells in a time- and concentration-dependent manner.

Regarding data presented in Figure 4, the methanolic extract of A. baetica roots induced antiproliferative effects on T-24 and HT-29 cell lines with IC $_{50} 48 \pm 5 \mu \mathrm{g} / \mathrm{ml}$ and $100 \pm 10 \mu \mathrm{g} / \mathrm{ml}$, respectively. Both T-24 and HT-29 cell lines were more sensitive to the effect of extract of $A$. baetica than Hep G-2 cell lines with $\mathrm{IC}_{50} 380 \pm 7 \mu \mathrm{g} / \mathrm{ml}$. There is a significant difference between $\mathrm{IC}_{50}$ value induced by the methanolic extract on all treated cancerous cells $\left(p^{* *}<0.05\right)$.

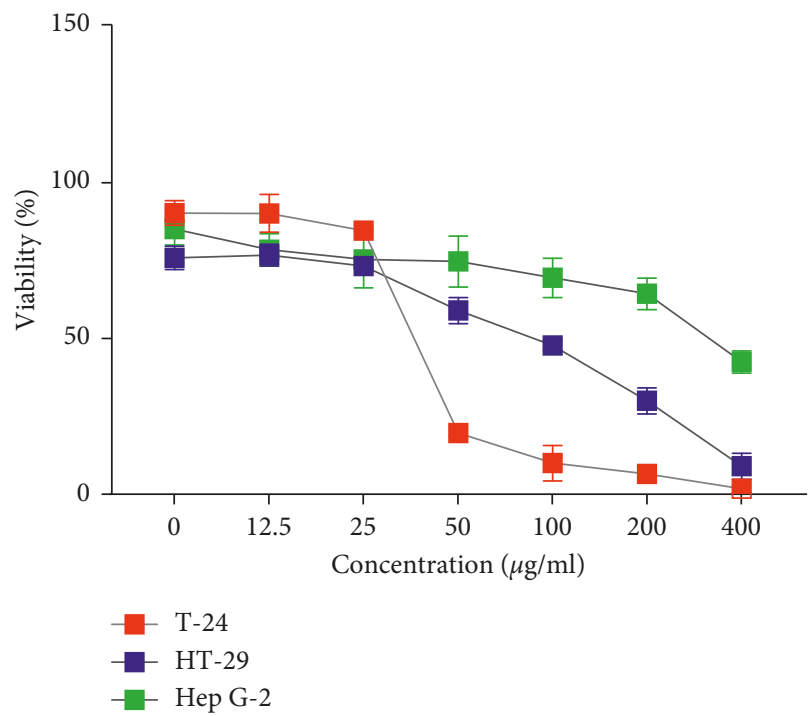

FIGURE 4: Cell viability after $72 \mathrm{~h}$ of treatment with the methanolic extract of $A$. baetica roots.

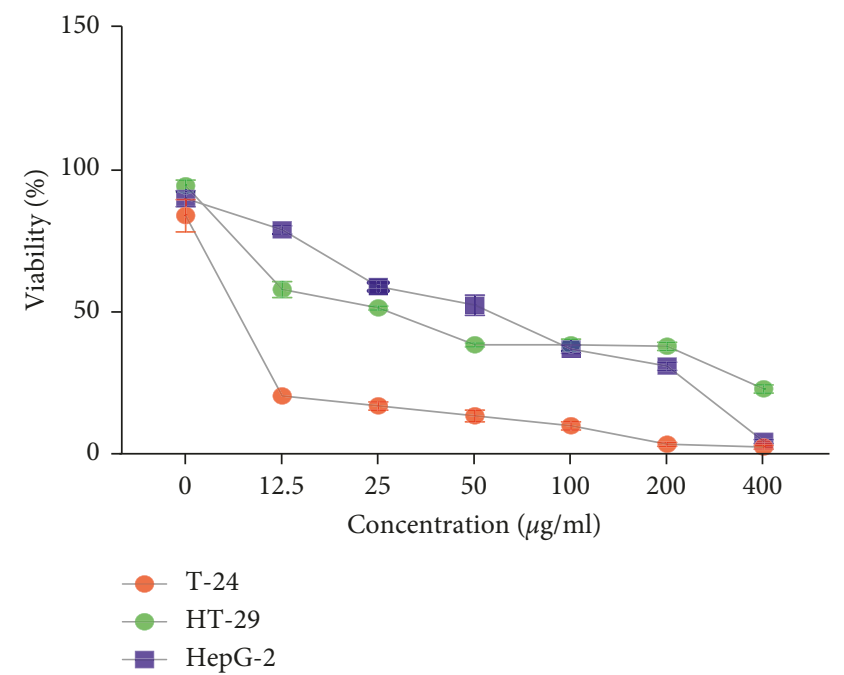

FIGURE 5: Cell viability after $72 \mathrm{~h}$ of treatment with the methanolic extract of $A$. paucinervis roots.

In Figure 5, the methanolic extract of A. paucinervis roots exerts antiproliferative effects on Hep G-2 and HT29 cell lines with $\mathrm{IC}_{50}$ approximately $52 \pm 5 \mu \mathrm{g} / \mathrm{ml}$ and $30 \pm 6 \mu \mathrm{g} / \mathrm{ml}$, respectively. The T-24 cell lines were more sensitive to organic extract of A. paucinervis roots than Hep G-2 and HT-29 with $\mathrm{IC}_{50} 6 \pm 1 \mu \mathrm{g} / \mathrm{ml}$. To perform the 
comparison, there is a significant difference between $\mathrm{IC}_{50}$ value induced by the methanolic extract of $A$. paucinervis roots on the treated cells (T-24, HT-29, and Hep G-2) $\left(p^{* *}<0.05\right)$.

3.6. Acute Toxicity Studies. The findings of acute toxicity study showed the absence of mortalities and signs of toxicity on the oral treated mice with both $2000 \mathrm{mg} / \mathrm{kg}$ of the methanolic extract of $A$. baetica roots and $2000 \mathrm{mg} / \mathrm{kg}$ methanolic extract of $A$. paucinervis roots. Slight changes in general behavior like running after the gavage compared to the control group were observed.

\section{Discussion}

Since prehistoric times, the medicinal plants have played a central role in the prevention and the treatment of various diseases [19]. In the current work, we decided to scientifically highlight the traditional uses of Moroccan $A$. baetica and $A$. paucinervis roots, such as to investigate their chemical profile, antioxidant activity, antiproliferative effect, and acute toxicity.

The phytochemical profile of the two studied plants in this work revealed the presence of alkaloids polyphenols, flavonoids, tannins, saponins, and the absence of anthraquinone, sterols, and terpenes. These results were in accordance with those reported in earlier reports which showed that the phytochemical screening of $A$. longa and A. baetica roots revealed the presence of phenols, flavonoids, saponins, and the absence of anthraquinones, sterols, and triterpenes $[17,20]$. The qualitative test of the aerial parts of $A$. indica showed positive tests for terpenes, saponins, tannins, and flavonoids [21].

Plants with high amounts of phytoconstituents such as flavonoids and polyphenols are reported to exhibit antioxidant properties [16]. In the current research work, the total polyphenolic content was quantified using the FolinCiocalteau assay [22]. The rate of total polyphenolic content of methanolic extract of $A$. baetica and $A$. paucinervis roots was estimated at $360 \pm 20 \mathrm{mg} \mathrm{GAE} / \mathrm{g}$ and $280 \pm 27 \mathrm{mg} \mathrm{GAE} /$ $\mathrm{g}$, respectively. The total flavonoids content of $A$. baetica and A. paucinervis extracts were estimated at $35 \pm 8 \mathrm{mg} \mathrm{QE} / \mathrm{g}$ and $235 \pm 7 \mathrm{mg} \mathrm{QE} / \mathrm{g}$. These findings were partly comparable to those reported in previous literature [21], in which it was reported that the total polyphenolic and flavonoids content shown in aqueous extract of $A$. indica was $25.11 \pm 0.18 \mathrm{GAE} /$ $\mathrm{g}$ and $30.41 \pm 0.19 \mathrm{QE} / \mathrm{g}$, respectively.

In the present investigation, a proposing DPPH radical scavenging activity was noticed for the methanolic extract of A. baetica and $A$. paucinervis with $\mathrm{IC}_{50}$ values of $150 \pm 8 \mu \mathrm{g} /$ $\mathrm{ml}$ and $160 \pm 10 \mu \mathrm{g} / \mathrm{ml}$, respectively. This property could be attributed to presence of interesting total polyphenolic content [23]. The antioxidant activity of polyphenols is due to their redox properties which could play a central role in capturing and neutralizing free radicals in order to prevent their harmful effects [24]. To the best of our knowledge, no previous data were available for A. baetica and A. paucinervis antioxidant activity. Thus, other plants of genus Aristolochia were phytochemically and biologically evaluated to perform comparison. The obtained results were in confirmation with early reports concerning DPPH radical scavenging activity of $A$. longa organic extract which showed a $\mathrm{DPPH} \mathrm{IC}_{50}$ value of $\mathrm{IC}_{50}$ equal $125.40 \pm 2.40 \mu \mathrm{g} / \mathrm{mL}$ [25].

Regarding the antiproliferative activity, the results showed that the methanolic extract of $A$. baetica roots exhibited a high antiproliferative effect on T-24, HT-29, and Hep G-2 cell lines with $\mathrm{IC}_{50}$ approximately of $48 \pm 5 \mu \mathrm{g} / \mathrm{ml}$, $100 \pm 10 \mu \mathrm{g} / \mathrm{ml}$, and $380 \pm 7 \mu \mathrm{g} / \mathrm{ml}$, respectively. On the other hand, the methanolic extract of $A$. paucinervis showed $\mathrm{IC}_{50}$ values of $52 \pm 5 \mu \mathrm{g} / \mathrm{ml}, 30 \pm 6 \mu \mathrm{g} / \mathrm{ml}$, and $6 \pm 1 \mu \mathrm{g} / \mathrm{ml}$ on Hep G-2, HT-29, and T-24, respectively. To perform the comparison, it was reported that the antiproliferative effect of $A$. baetica organic extracts was estimated at $\mathrm{IC}_{50}$ : $216.06 \pm 15 \mu \mathrm{g} / \mathrm{mL}$ [8]. The remarkable antiproliferative effect resulted in methanolic extracts of the studied plants was in accordance with previous data [26], in which it was reported that the $\mathrm{IC}_{50}$ value of $A$. longa aqueous extract against human cancer lines was determined at $15,63 \mu \mathrm{g} / \mathrm{ml}$.

Dysregulation of apoptosis is one of the most important factors intervened in cancer treatment [27]. The control of cancer growth still related to the ability of cancer cells to undergo apoptosis [28]. The mechanism by which genus Aristolochia could induce cell death was investigated in previous literature [29], it was reported that the aqueous extract of A. longa induces apoptosis through the mitochondrial intrinsic pathway in BL41. This mechanism could involve in our treated cell lines with methanolic extracts of the studied plants. The phytochemical screening revealed the presence of polyphenols, alkaloids, flavonoids, and tannins. On the other hand, the pharmacological activities of plants rely on their chemical compounds, and thus, the antiproliferative activity of the studied plants is associated with the detected compounds [30]. The detected flavonoids could be the responsible compounds for the antiproliferative activity [31].

Mass spectrometry plays a crucial role in the development of the organic field because of its efficiency in the qualitative and quantitative determination of organic molecules. Gas chromatography coupled to a mass spectrometer (GC-MS) permits a mixture of small molecules rather than organic constituent of low molecular weight to be analyzed [32]. Ten compounds namely pseudocumene, tetracyclo [3.3.1.0.1(3,9)] decan-10-one, $p$-vinylguaiacol, 2 epi-trans- $\beta$-caryophyllene, guaia-6,9-diene, pacifigorgiol, maaliol, methylglucose, isoaromadendrene epoxide, and trans-sinapyl alcohol were identified in methanolic extract of A. baetica using GC-MS. On the other hand, seven compounds such as dihydro-4,4,5,5-tetramethyl $2(3 \mathrm{H})$ furanone, mesitylene, dodecane, maaliol, 2-palmitoylglycerol, dioctyl terephthalate, phthalic acid, and $\operatorname{di}(2$ propylpentyl) ester were detected from the methanolic extract of $A$. baetica roots.

The pharmacological and biological properties of the studied plants in the current work seem to be attributed to the identified compounds. This can be a result of the action of a single molecule or by a synergy between all these molecules without excluding the potentiation effects. As an example, pacifigorgiol found in the methanolic extract of 
A. baetica was reported in previous literature to exhibit antibacterial activities [33]. A cytotoxic effect against brine shrimp nauplii Artemia salina was attributed to dioctyl terephthalate detected in the methanolic extract of A. paucinervis [34].

The acute toxicity of the investigated methanolic in this work was useful to provide information concerning the safety control for potential uses in single administration. No clinical signs nor mortalities occurred in animals treated orally with $2000 \mathrm{mg} / \mathrm{kg}$ of the two plant extracts compared to control groups. Therefore, the predicted $\mathrm{LD}_{50}$ of the studied plant extracts would be higher than $2000 \mathrm{mg} /$ $\mathrm{kg}$. On the other hand, these extracts seem to be safe for animals with oral administration of single doses up to $2000 \mathrm{mg} / \mathrm{kg}$ under the conditions of acute toxicity. The present results were consolidated to other researches which showed the safety of single administered doses to mice (lower than $4 \mathrm{~g} / \mathrm{kg}$ ) $[17,35]$. In the same way, the methanolic extract of $A$. baetica and A. paucinervis roots was not toxic with single doses according to the scale of Viala [32]. However, the genus Aristolochia exhibits high toxicity when ingested for a long time with repeated doses $[36,37]$.

\section{Conclusion}

Phytochemical profile of both A. baetica and A. paucinervis was useful to provide information on the potential of these plants as a promising source of secondary metabolites, hence, encouraging their natural potential as a source of various therapeutic agents for the treatment of cancer.

\section{Data Availability}

All data are available in the following laboratories: Laboratory of Chemistry, Biochemistry, Nutrition, and Environment, Faculty of Medicine and Pharmacy, University Hassan II, Casablanca, Morocco; Research Unit and Medical Biology, National Center for Nuclear Energy, Science and Technology, CNESTEN. Rabat 10001, Morocco; Laboratory REMTEX, Higher School of Textile and Clothing Industries, Km 8, Route d'EL JADIDA, Casablanca, Morocco; and Faculty of Sciences Ben M'Sik, University Hassan II Casablanca. B. P. 7955, Morocco Laboratory of Engineering and Materials LIMAT, Faculty of Sciences Ben M'Sik, University Hassan II Casablanca. B. P. 7955, Morocco.

\section{Conflicts of Interest}

The authors declare that they have no conflicts of interest.

\section{Acknowledgments}

The authors extend their appreciation to the Deanship of Scientific Research at King Saud University for funding this work through research group no. RG-1440-009.

\section{References}

[1] W. H. Lewis, Medicinal Botany Plants Affecting Man's Health, John Wiley \& Sons, New York, NY, USA, 1977.
[2] R. Verpoorte, "Chemodiversity and the biological role of secondary metabolites, some thoughts for selecting plant material for drug development," in Bioassay Methods in Natural Product Research and Drug Development, Springer, Berlin, Germany, 1999.

[3] M. Gupta, U. K. Mazumder, T. S. Kumar, P. Gomathi, and R. S. Kumar, "Antioxidant and hepatoprotective effects of Bauhinia racemosa against paracetamol and carbon tetrachloride induced liver damage in rats," Iranian Journal of Pharmacology and Therapeutics, vol. 3, no. 1, p. 12, 2004.

[4] L. Bachiri, N. Labazi, A. Daoudi et al., "Etude ethnobotanique de quelques lavandes marocaines spontanées," International Journal of Biological and Chemical Sciences, vol. 9, no. 3, pp. 1308-1318, 2015.

[5] S. Mathew and T. E. Abraham, "In vitro antioxidant activity and scavenging effects of Cinnamomum verum leaf extract assayed by different methodologies," Food and Chemical Toxicology, vol. 44, no. 2, pp. 198-206, 2006.

[6] D. J. Newman and G. M. Cragg, "Natural products as sources of new drugs over the last 25 years $\perp$," Journal of Natural Products, vol. 70, no. 3, pp. 461-477, 2007.

[7] M. Bourhia, A. A. Shahat, O. M. Almarfadi et al., "Ethnopharmacological survey of herbal remedies used for the treatment of cancer in the greater Casablanca-Morocco," Evidence-Based Complementary and Alternative Medicine, vol. 2019, Article ID 1613457, 9 pages, 2019.

[8] W. Chaouki, D. Y. Leger, J. Eljastimi, J.-L. Beneytout, and M. Hmamouchi, "Antiproliferative effect of extracts from Aristolochia baetica and Origanum compactumon human breast cancer cell line MCF-7," Pharmaceutical Biology, vol. 48, no. 3, pp. 269-274, 2010.

[9] A. Ouarghidi, G. J. Martin, B. Powell, G. Esser, and A. Abbad, "Botanical identification of medicinal roots collected and traded in Morocco and comparison to the existing literature," Journal of Ethnobiology and Ethnomedicine, vol. 9, no. 1, p. 59, 2013.

[10] W. H. Lewis and M. P. F. Elvin Lewis, Medical Botany. Plants Affecting Man's Health, vol. 196, Wiley, Hoboken, NJ, USA, 1977.

[11] E. J. Kadhim, "Phytochemical investigation and hepatoprotective studies of Iraqi Bryonia dioica (Family Cucurbitaceae)," International Journal of Pharmacy and Pharmaceutical Sciences, vol. 6, no. 4, pp. 187-190, 2014.

[12] N. Belkacem, R. Djaziri, F. Lahfa, I. A. El-Haci, and Z. Boucherit, "Phytochemical screening and in vitro antioxidant activity of various Punica granatum L. peel extracts from Algeria: a comparative study," Phytothérapie, vol. 12, no. 6, pp. 372-379, 2014.

[13] N. Benariba, R. Djaziri, W. Bellakhdar et al., "Phytochemical screening and free radical scavenging activity of Citrullus colocynthis seeds extracts," Asian Pacific Journal of Tropical Biomedicine, vol. 3, no. 1, pp. 35-40, 2013.

[14] B. Senhaji, B. Chebli, E. Mayad et al., "Phytochemical screening, quantitative analysis and antioxidant activity of Asteriscus imbricatus and Pulicaria mauritanica organic extracts," International Food Research Journal, vol. 24, no. 6, pp. 2482-2489, 2017.

[15] P. Maisuthisakul, M. Suttajit, and R. Pongsawatmanit, "Assessment of phenolic content and free radical-scavenging capacity of some Thai indigenous plants," Food Chemistry, vol. 100, no. 4, pp. 1409-1418, 2007.

[16] H. Makrane, M. El Messaoudi, A. Melhaoui, M. El Mzibri, L. Benbacer, and M. Aziz, "Cytotoxicity of the aqueous extract and organic fractions from Origanum majorana on human 
breast cell line MDA-MB-231 and human colon cell line HT29," Advances in Pharmacological Sciences, vol. 2018, Article ID 3297193, 9 pages, 2018.

[17] M. Bourhia, A. A. Haj Said, A. Chaanoun et al., "Phytochemical screening and toxicological study of Aristolochia baetica linn roots: histopathological and biochemical evidence," Journal of Toxicology, vol. 2019, Article ID 8203832, 7 pages, 2019.

[18] OECD (Organization for Economic Cooperation \& Development), OECD Guidelines for the Testing of Chemicals. Test Guidelines 425. Acute Oral Toxicity: Up-And- Down Procedure, OECD, Paris, France, 2008.

[19] B. Assefa, G. Glatzel, and C. Buchmann, "Ethnomedicinal uses of Hagenia abyssinica (Bruce) J. F. Gmel. among rural communities of Ethiopia," Journal of Ethnobiology and Ethnomedicine, vol. 6, no. 1, p. 20, 2010.

[20] B. Benarba and B. Meddah, "Ethnobotanical study, antifungal activity, phytochemical screening and total phenolic content of Algerian Aristolochia longa," Journal of Intercultural Ethnopharmacology, vol. 3, no. 4, p. 150, 2014.

[21] V. Subramaniyan, R. Saravanan, D. Baskaran, and S. Ramalalingam, "In vitro free radical scavenging and anticancer potential of Aristolochia indica L. against MCF-7 cell line," International Journal of Pharmacy and Pharmaceutical Sciences, vol. 7, no. 6, pp. 392-396, 2015.

[22] M. López-Vélez, F. Martinez-Martínez, and C. D. Valle-Ribes, "The study of phenolic compounds as natural antioxidants in wine," Critical Reviews in Food Science and Nutrition, vol. 43, no. 2, pp. 233-244, 2003.

[23] F. Shahidi, P. K. Janitha, and P. D. Wanasundara, "Phenolic antioxidants," Critical Reviews in Food Science and Nutrition, vol. 32, no. 1, pp. 67-103, 1992.

[24] T. Osawa, "Novel natural antioxidants for utilization in food and biological systems," in Postharvest Biochemistry of Plant Food-Materials in the Tropics, pp. 241-251, Japan Scientific Societies Press, Tokyo, Japan, 1994.

[25] N. El Omari, K. Sayah, S. Fettach et al., "Evaluation of in vitro antioxidant and antidiabetic activities of Aristolochia longa extracts," Evidence-Based Complementary and Alternative Medicine, vol. 2019, Article ID 7384735, 9 pages, 2019.

[26] B. Benarba, A. Aoues, A. Vazquez, G. Ambroise, and B. Meddah, "Aristolochia longa aqueous extract triggers the mitochondrial pathway of apoptosis in BL41 Burkitt's lymphoma cells," International Journal of Green Pharmacy, vol. 6, no. 1 , p. $45,2012$.

[27] M. M. Chamorro, J. D. Regan, L. A. Opperman, and P. R. Kramer, "Effect of storage media on human periodontal ligament cell apoptosis," Dental Traumatology, vol. 24, no. 1, pp. 11-16, 2008.

[28] G. M. Cohen, "Caspases: the executioners of apoptosis," Biochemical Journal, vol. 326, no. 1, pp. 1-16, 1997.

[29] B. Benarba, B. Meddah, and A. Aoues, "Bryonia dioica aqueous extract induces apoptosis through mitochondrial intrinsic pathway in BL41 Burkitt's lymphoma cells," Journal of Ethnopharmacology, vol. 141, no. 1, pp. 510-516, 2012.

[30] S. R. Hashemi, I. Zulkifli, and B. M. Hair, "Acute Toxicity Study and Phytochemical Screening of Selected Herbal Aqueous Extract in Broiler Chickens," International Journal of Pharmacology, vol. 4, no. 5, pp. 352-360, 2008.

[31] L. Barros, M. Dueñas, I. C. F. R. Ferreira, A. Maria Carvalho, and C. Santos-Buelga, "Use of HPLC-DAD-ESI/MS to profile phenolic compounds in edible wild greens from Portugal," Food Chemistry, vol. 127, no. 1, pp. 169-173, 2011.
[32] K. R. Asha, S. Priyanga, S. Hemmalakshmi, and K. Devaki, "GC-MS analysis of the ethanolic extract of the whole plant Drosera indica L.," International Journal of Pharmacognosy and Phytochemical Research, vol. 9, no. 5, pp. 685-688, 2017.

[33] R. R. Izac, S. E. Poet, W. Fenical, D. Van Engen, and J. Clardy, "The structure of pacifigorgiol, an ichthyotoxic sesquiterpenoid from the pacific gorgonian coral," Tetrahedron Letters, vol. 23, no. 37, pp. 3743-3746, 1982.

[34] M. R. Habib and M. R. Karim, "Antimicrobial and cytotoxic activity of di-(2-ethylhexyl) phthalate and anhydrosophoradiol-3-acetate isolated from Calotropis gigantea (Linn.) flower," Mycobiology, vol. 37, no. 1, pp. 31-36, 2009.

[35] M. Bourhia, A. Lahmadi, H. Achtak et al., "Phytochemical analysis and toxicity study of Aristolochia paucinervis rhizomes decoction used in Moroccan alternative medicine: histopathological and biochemical profiles," Evidence-Based Complementary and Alternative Medicine, vol. 2019, Article ID 1398404, 11 pages, 2019.

[36] H. S. Cherif, F. Saidi, and A. Guedioura, "Toxicological evaluation of Aristolochia longa L. extract in mice," Indian Journal of Applied Research, vol. 4, no. 5, pp. 26-30, 2014.

[37] G. Benzakour, M. Amrani, and M. Oudghiri, "A histopathological analyses of in vivo anti-tumor effect of an aqueous extract of Aristolochia longa used in cancer treatment in traditional medicine in Morocco," International Journal of Plant Research, vol. 2, no. 2, pp. 31-35, 2012. 


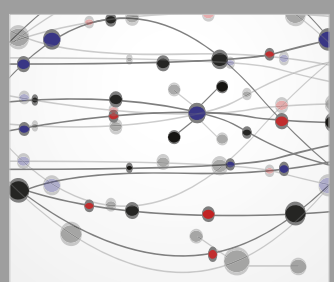

The Scientific World Journal
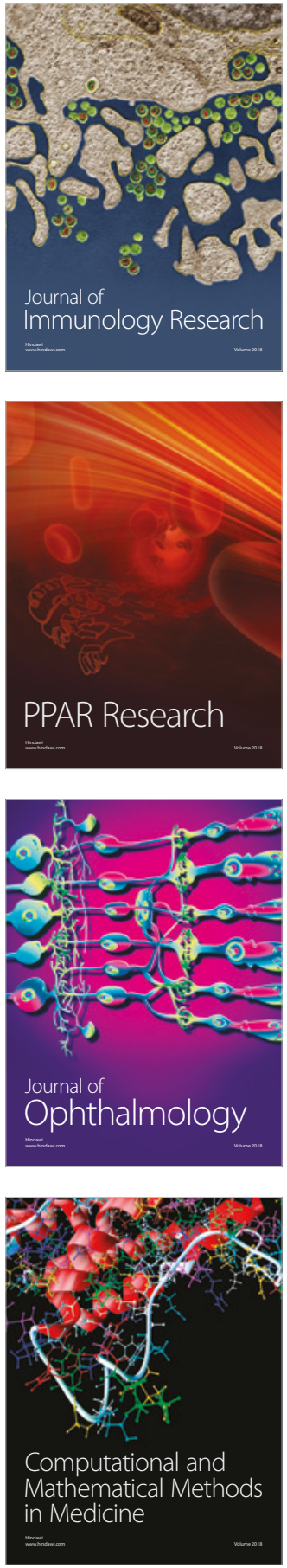

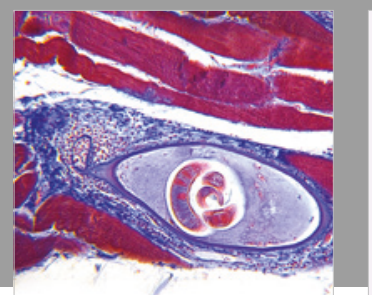

Gastroenterology Research and Practice

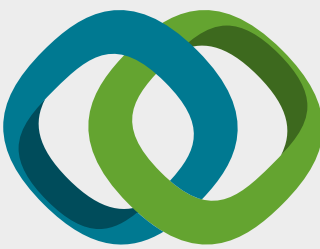

\section{Hindawi}

Submit your manuscripts at

www.hindawi.com
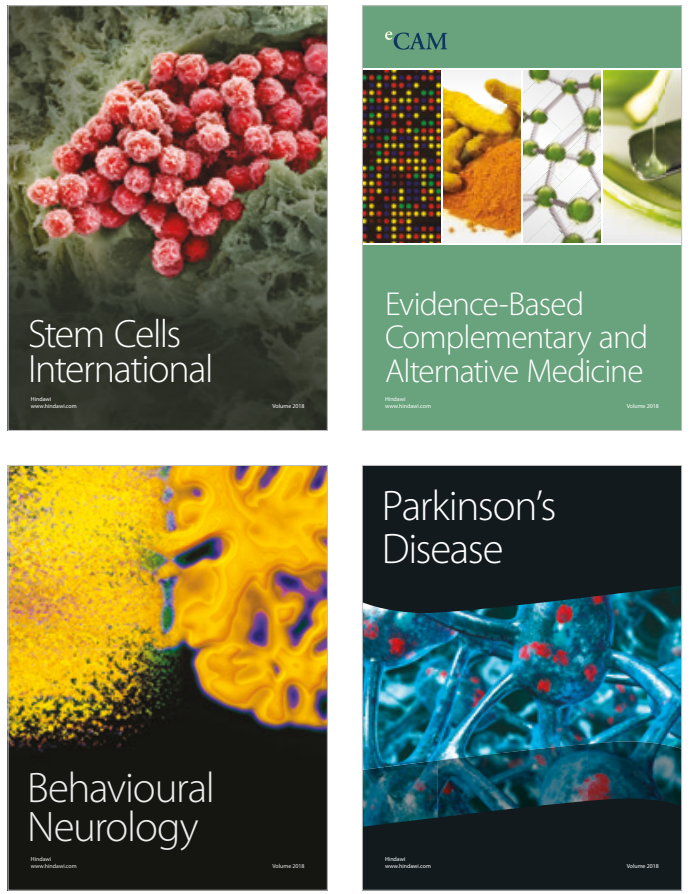

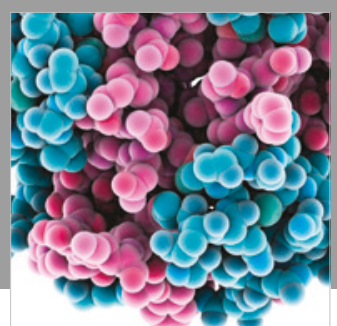

ournal of

Diabetes Research

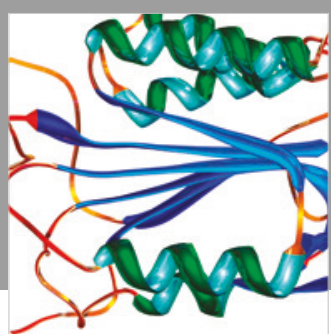

Disease Markers
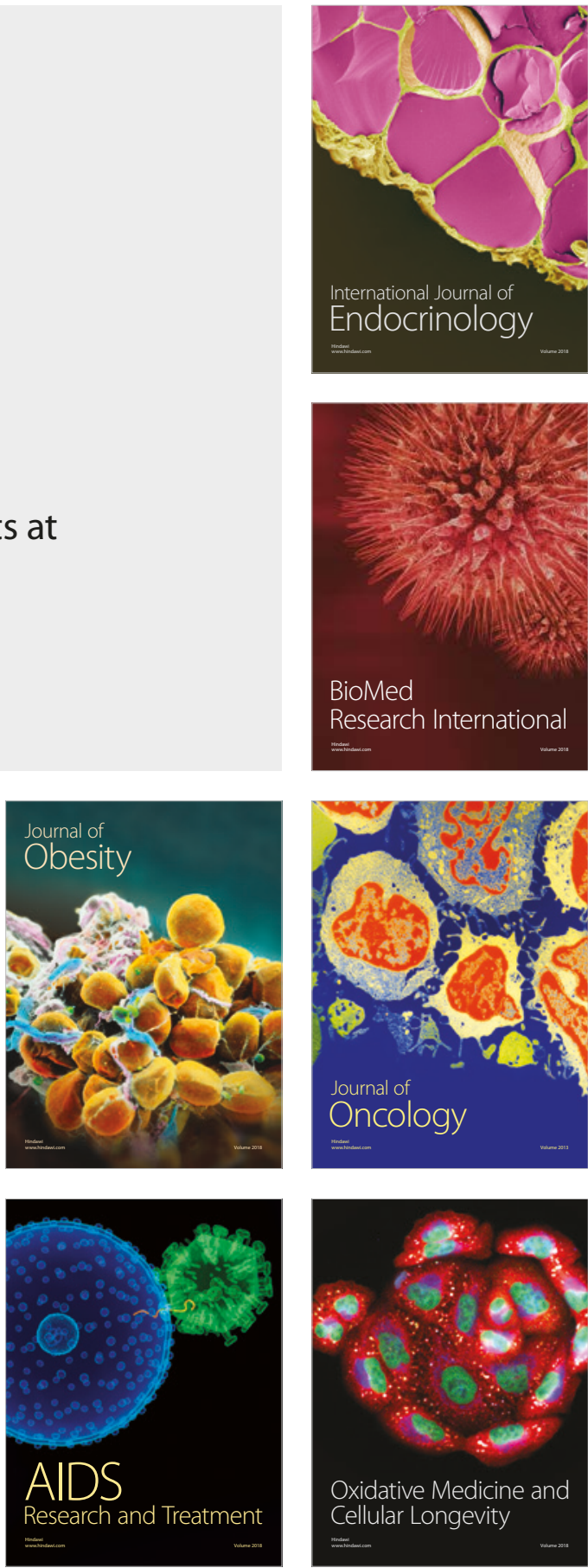